\title{
Pengaruh Kepemilikan Saham Asing, Kualitas Informasi Internal, Publisitas CEO, ROA, Leverage dan Ukuran Perusahaan terhadap Penghindaran Pajak
}

\author{
Muhammad Akbar ${ }^{1 *}$, Teddy Chandra ${ }^{2)}$, Rini Yayuk Priyati ${ }^{3)}$ \\ ${ }^{1 *}$, 3) Program Studi Magister Manajemen, Fakultas Ekonomi, Universitas Terbuka \\ Jl. Cabe Raya, Pondok Cabe, Pamulang, Tangerang Selatan 15418 \\ ${ }^{2)}$ Institut Bisnis dan Teknologi Pelita Indonesia, Program Studi Manajemen \\ J1. Jendral Ahmad Yani No. 78 - 88, Pekanbaru, Riau, 28127 \\ E-mail: 530015114@ecampus.ut.ac.id $\left.{ }^{1 *}\right)$
}

\begin{abstract}
ABSTRAK
Tujuan penelitian ini adalah untuk mengetahui pengaruh pengaruh kepemilikan saham asing, kualitas informasi internal, publisitas chief executive officer, return on asset, leverage dan ukuran perusahaan terhadap penghindaran pajak pada perusahaan pertambangan yang terdaftar di BEI tahun 2010 sampai dengan 2018. Alat analisis yang digunakan dalam penelitian ini adalah regresi linear berganda. Hasil pengolahan data diperoleh model $Y=0,329-0,082 \mathrm{KSA}-0,002 \mathrm{KII}+0,001$ PCEO + 0,118 ROA + 0,107 LEV + 0,011 UKP + e. Secara parsial, hasil uji t menunjukkan bahwa variabel kepemilikan saham asing, kualitas informasi internal, publisitas CEO, leverage, dan ukuran perusahaan berpengaruh terhadap penghindaran pajak, namun return on asset tidak berpengaruh terhadap penghindaran pajak. Hasil analisis menunjukkan bahwa variabel penghindaran pajak dipengaruhi oleh variabel independen sebesar $14 \%$.
\end{abstract}

Kata kunci: Kepemilikan Saham Asing; Kualitas Informasi Internal; Leverage; Penghindaran Pajak; Ukuran Perusahaan

\begin{abstract}
The purpose of this study is to determine the effect of foreign share ownership, quality of internal information, publicity of chief executive officer, return on assets, leverage and company size on tax avoidance in mining companies listed on the IDX from 2010 to 2018. Analytical tools used in This study is a multiple linear regression. The results of data processing obtained model $Y=0.329-0.082 \mathrm{KSA}$ $0.002 \mathrm{KII}+0.001$ PCEO + 0.118 ROA + 0.107 LEV + 0.011 UKP + e. Partially, the results of the test show that the variables of foreign share ownership, internal information quality, CEO publicity, leverage, and company size have an effect on tax avoidance, but return on assets has no effect on tax avoidance. The analysis results show that the tax avoidance variable is influenced by the independent variable by $14 \%$.
\end{abstract}

Keyword: Firm Size; Foreign Share Ownership; Leverage; Quality of Internal Information; Tax Avoidance.

\section{PENDAHULUAN}

Perusahaan sebagai salah satu wajib pajak memiliki kewajiban untuk membayar pajak sesuai dengan ketentuan perpajakan. Besarnya pajak yang harus disetorkan ke kas negara tergantung dari besarnya jumlah laba yang didapat perusahaan selama satu tahun. Dalam lima 
tahun terakhir realisasi penerimaan pajak tidak sesuai dengan target yang telah ditetapkan oleh pemerintah. Pelaksanaan pemungutan pajak oleh pemerintah tidaklah selalu mendapat sambutan yang baik dari perusahaan. Hal tersebut diakibatkan oleh perbedaan kepentingan antara fiskus yang menginginkan penerimaan pajak yang besar dan kontinyu yang bertolak belakang dengan kepentingan dari perusahaan yang menginginkan pembayaran pajak seminimal mungkin (Hardika, 2007). Perbedaan kepentingan inilah yang menyebabkan wajib pajak cenderung mengurangi jumlah pajaknya, baik secara legal maupun illegal. Meminimalkan pembayaran pajak dapat dilakukan dengan berbagai cara, mulai dari dalam bingkai peraturan perpajakan sampai dengan yang melanggar peraturan perpajakan. Upaya minimalisasi pajak ini disebut dengan perencanaan pajak (tax planning). Meminimalkan kewajiban pajak yang tidak melanggar undang-undang sering disebut dengan tax avoidance. Praktik tax avoidance biasanya memanfaatkan kelemahan-kelemahan hukum pajak dan tidak melanggar hukum perpajakan (Sari, 2013).

Penghindaran pajak terkait dengan faktor kondisi keuangan perusahaan diantaranya kepemilikan saham asing. Kepemilikan saham asing merupakan penyertaan saham pada suatu perusahaan yang dimiliki individu, dan atau institusi yang berasal dari luar Indonesia atau asing. Beberapa peneliti telah melakukan penelitian mengenai keberadaaan investor asing pada suatu perusahaan, seperti (Rusydi, 2014) menyimpulkan kepemilikan asing tidak berpengaruh terhadap tindakan pajak agresi, dikarenakan oleh adanya implikasi perusahaan milik asing akan lebih patuh dengan aturan yang berlaku di perusahaan tersebut beroeperasi sesuai dengan asumsi internasional bahwa perusahaan asing mematuhi peraturan yang berlaku. Salihu et al (2015) menemukan bahwa terdapat pengaruh signifikan antara kepemilikan investor asing dengan penghindaran pajak pada perusahaan di Malaysia.

Faktor selain dari kepemilikan saham asing, melainkan kualitas informasi internal juga merupakan faktor yang dapat berpengaruh terhadap penghindaran pajak. Arus informasi pada manajemen perusahaan yang berkualitas akan membantu manajemen perusahaan menghasilkan kebijakan perusahaan yang efektif, salah satunya kebijakan mengenai penghindaran pajak perusahaan. Menurut Gallemore \& Labro (2015) tanpa informasi yang baik, peluang perencanaan pajak mungkin tidak terlihat, koordinasi perencanaan pajak di seluruh segmen usaha atau geografis mungkin sangat sulit atau bahkan tidak mungkin, dan risiko yang diambil dalam mengejar strategi pajak yang agresif mungkin sangat tinggi. Penelitian tentang kualitas informasi internal telah dilakukan oleh (Ghafoori \& Rahmani, 2017), dengan objek penelitian pada perusahaan yang terdaftar di Bursa Efek Teheran. Dampak kualitas informasi internal pada penghindaran pajak lebih tinggi pada perusahaan 
yang memiliki informasi yang berkualitas dibandingkan dengan perusahan yang tersebar diberbagai wilayah dan perusahaan yang memiliki berbagai sektor usaha.

Disamping itu, faktor lain yang mempengaruhi penghindaran pajak adalah publisitas Chief Executive Officer (CEO). CEO adalah kepemimpinan tertinggi pada perusaahaan yg diberikan kekuasaan atau wewenang untuk mengatur jalannya kegiatan operasional perusahaan (Putri \& Fadhlia, 2017). CEO dengan publisitas tinggi mampu mengendalikan perusahaan melalui kebijakan penghindaran pajak yang ia tetapkan sehingga manajemen mendapatkan kompensasi dan juga berdampak positif pada perusahaan yakni meningkatkan nilai saham perusahaan sehingga semakin banyak investor yang tertarik menanamkan sahamnya pada perusahaan tersebut. Duan et al (2018) membuktikan bahwa CEO dengan publisitas tinggi cenderung menggunakan penghindaran pajak untuk meningkatkan laba yang dilaporkan dan memenuhi harapan kinerja pasar.

Faktor lain yang dapat mempengaruhi perusahaan untuk melakukan penghindaran pajak (tax avoidance) adalah ROA. Pendekatan ROA menggambarkan besarnya laba yang diperoleh perusahaan dengan menggunakan total aset yang dimilikinya. ROA yang meningkat berarti perusahaan mampu mengefesiensikan aset yang dimiliki sehingga mampu menghasilkan laba yang besar, dengan demikian pajak yang dikenakan akan besar, perusahaan tentu tidak menginginkan pembayaran pajak seperti ini, sehingga perusahaan mengupayakan tindakan yang dapat meminimalkan pembayaran pajak atau ada indikasi perusahaan akan melakukan penghindaran pajak. Penelitian ini didukung oleh penelitian sebelumnya yang dilakukan oleh Sinambela (2019), Heryuliani (2015) dan Ajie (2015) yang menyimpulkan bahwa return on asset berpengaruh terhadap penghindaran pajak (tax avoidance). Berbeda dengan Peneliti lainnya yaitu (Marfu'ah, 2015), dan (Rachmitasari, 2015) menyimpulkan bahwa return on asset tidak berpengaruh terhadap penghindaran pajak (tax avoidance).

Perusahaan dalam memperoleh aset ataupun menjalankan kegiatan operasionalnya, tentu membutuhkan dana. Salah satu sumber dana ini ada yang berasal dari pinjaman luar perusahaan. Leverage adalah penggunaan dana dari pihak eksternal berupa hutang untuk membiayai investasi dan asset perusahaan (Ngadiman \& Puspitasari, 2014). Timbulnya utang pada perusahaan tentu akan muncul beban bunga. Perlu diperhatikan bahwa beban bunga yang hanya berasal dari pinjaman pihak ketiga atau yang tidak memiliki hubungan dengan perusahaan yang dapat dijadikan pengurang laba kena pajak. Semakin tinggi tingkat utang maka diindikasikan semakin tinggi pula perusahaan melakukan penghindaran pajak (Ardiana, 2015). Hal ini didukung oleh sejumlah peneliti yaitu Sinambela (2019) dan Rachmitasari (2015) yang menyimpulkan bahwa leverage berpengaruh terhadap penghindaran pajak. 
Namun, berbeda dengan penelitian yang dilakukan oleh Prakosa (2014) dan Luh \& Puspita (2017) menyimpulkan bahwa leverage tidak berpengaruh terhadap penghindaran pajak.

Faktor terakhir yang dapat mempengaruhi perusahaan untuk melakukan penghindaran pajak adalah ukuran perusahaan. Ukuran perusahaan dapat dilihat dari aset yang dimiliki suatu perusahaan. Semakin besar aset yang dimiliki perusahaan menunjukkan semakin besar pula ukuran perusahaan tersebut. Aset yang besar pada perusahaan besar sehingga perusahaan besar tersebut mampu memperoleh laba yang besar. Oleh sebab itu, perusahaan akan membayar pajak dalam jumlah besar. Darmawan \& Sukartha (2014) dan Marfu'ah (2015) menyimpulkan ukuran perusahaan berpengaruh terhadap penghindaran pajak. Hasil penelitian ini berbeda dengan penelitian yang dilakukan oleh Sinambela (2019) menyimpulkan bahwa ukuran perusahaan tidak berpengaruh terhadap penghindaran pajak.

Penelitian ini perlu di teliti dikarenakan penghindaran pajak di Indonesia dapat dilihat dari rasio pajak atau tax ratio di Negara Indonesia. Rasio pajak dalam kurun waktu tiga tahun terakhir hanya mencapai 10,7 persen, 11,5 persen dan 10,6 persen (kemenkeu.go.id, 2019). Fenomena rata-rata rasio pajak yang belum mencapai target dapat mengindikasikan adanya aktivitas penghindaran pajak yang cukup besar, sehingga penerimaan pajak negara Indonesia masih belum optimal (Darmawan \& Sukartha, 2014).

Berdasarkan latar belakang masalah tersebut, dapat diketahui tujuan penelitian ini yaitu untuk mengetahui dan menganalisis pengaruh kepemilikan saham asing, kualitas informasi internal, publisitas CEO, return on assets, leverage, dan ukuran perusahaan terhadap penghindaran pajak pada perusahaan pertambangan yang terdaftar di BEI selama periode 2010 sampai dengan 2018. Penelitian ini merupakan pengembangan dari penelitian sebelumnya yang dilakukan oleh Sinambela (2019) yang berjudul pengaruh ROA, leverage dan ukuran perusahaan terhadap penghindaran pajak. Hasil dari penelitian Sinambela (2019) ROA dan leverage berpengaruh terhadap penghindaran pajak, sedangkan ukuran perusahaan tidak berpengaruh terhadap penghindaran pajak. Perbedaan dari penelitian sebelumnya yang pertama, sampel yang digunakan dalam penilitian ini adalah perusahaan pertambangan yang terdaftar di BEI tahun 2010-2018 dengan harapan hasil penelitian ini menjadi lebih aktual dibandingkan dengan penelitian sebelumnya. Sedangkan perbedaan kedua adalah penulis menambahkan variabel Kepemlikan Saham Asing, Kualitas Informasi Internal dan Publisitas Chief Executive Officer yang diduga juga memicu terjadinya penghindaran pajak.

Penghindaran pajak merupakan tindakan yang berupaya meminimalkan pembayaran pajak dengan tidak melanggar ketentuan yang berlaku. Variabel ini dihitung melalui CETR (cash effective tax rate). CETR perusahaan yaitu kas yang dikeluarkan untuk biaya pajak 
dibagi dengan laba sebelum pajak. Adapun rumus untuk menghitung CETR dan adalah sebagai berikut:

$\mathrm{CETR}=\frac{\text { Pembayaran Pajak }}{\text { Laba Sebelum Pajak }}$

Kepemilikan saham asing didefinisikan sebagai perseroan atau kepemilikan saham yang dimiliki oleh warga negara asing atau institusi asing yang melakukan penanaman modal di Wilayah Indonesia. Struktur kepemilikan saham asing di atur dalam UU pasar modal yg mana dijelaskan bahwa pemegang saham menjadi pengendali saham sekitar 20 persen yang mana juga dijelaskan dalan peraturan PSAK NO 15 tentang besarnya pengaruh yg dimiliki pemegang saham sebesar 20 persen (Yuniasih, 2012).

Kepemilikan Saham Asing $=\frac{\text { Total Saham yang dimiliki Asing }}{\text { Total Saham yang beredar }}$

Menurut (Puspitawati, 2011), kualitas informasi merupakan karakteristik yang melekat pada informasi sehingga bermakna bagi pengguna dan memberikan keyakinan kepada pengguna dan dapat dalam mengambil keputusan. Penelitian yang dilakukan oleh Gallemore \& Labro (2015) menggunakan alat ukur dengan perhitungan kecepatan manajemen mengumumkan laporan tahunan. Perhitungan tersebut dapat dirumuskan sebagai berikut:

Kualitas Informasi Internal $=$ jumlah hari dari tanggal 31 Desember sampai tanggal publikasi

$$
\text { laporan keuangan tahunan perusahaan }
$$

Penelitian Duan et al (2018) mengukur publisitas CEO melalui Google Trends, dengan cara menginput nama CEO dan kode perusahaannya, data yang disajikan kemudian dirataratakan untuk periode satu tahun.

Publisitas CEO = Menggunakan SVI pada Google Trends

ROA adalah cara untuk mengukur suatu keuntungan yang didapatkan oleh perusahaan berdasarkan dari perhitungan seluruh total aset yang dimiliki Marfu'ah (2015). Rumus ROA adalah sebagai berikut:

$\mathrm{ROA}=\frac{\text { laba (rugi)bersih setelah pajak }}{\text { total aset }} \times 100 \%$

Rasio leverage adalah mengukur seberapa besar perusahaan dibiayai dengan utang (Fahmi, 2012). Pada penelitian ini leverage diukur dengan total debt to equity ratio dengan rumus sebagai berikut.

$L E V=\frac{\text { Total hutang }}{\text { Total aset }}$ 
Apabila perusahaan memiliki total aset yg besar maka akan mempermudah menilai suatu kualitas ukuran perusahaan tersebut. karena makin besar nya aset yg dimiliki makaa makin mempermudah perusahaan untuk mendapatkan dana di pasar modal (Ardansyah, 2014).

Size $=\log ($ Total Asset $)$

\section{KERANGKA PEMIKIRAN}

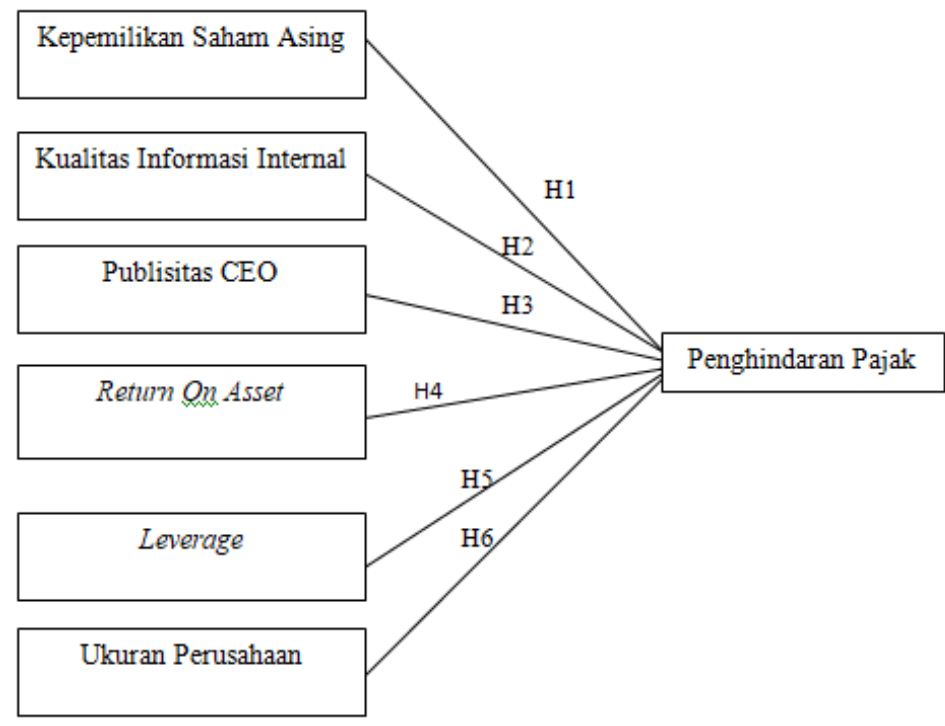

Gambar 1. Model Penelitian

Sumber: Jurnal Penelitian dikembangkan, 2020

Berdasarkan kerangka pemikiran tersebut, maka dapat dibuat suatu hipotesis dalam penelitian ini sebagai berikut:

Hipotesis 1 : Kepemilikan saham asing berpengaruh negatif terhadap penghindaran pajak.

Hipotesis 2 : Kualitas informasi internal berpengaruh positif terhadap penghindaran pajak.

Hipotesis 3 : Publisitas CEO berpengaruh positif terhadap penghindaran pajak.

Hipotesis 4 : Return on assets atau ROA berpengaruh postif terhadap penghindaran pajak.

Hipotesis 5 : Leverage berpengaruh positif terhadap penghindaran pajak.

Hipotesis 6 : Ukuran perusahaan berpengaruh positif terhadap penghindaran pajak.

\section{METODE PENELITIAN}

Populasi dalam penelitian ini 41 perusahaan Sub Sektor Pertambangan di BEI periode 2010-2018. Sedangkan proses penarikan sampel menggunakan metode purposive sampling. 
Adapun kriteria dalam penelitian yang digunakan yaitu (1) Perusahaan pertambangan yang memiliki Laporan Keuangan secara lengkap selama periode pengamatan (2) Perusahaan tidak delisting dan merger. Berdasarkan kriteria sampel tersebut, maka terdapat 21 perusahaan yang sesuai dengan kriteria sampel.

Teknik pengumpulan data dengan menggunakan teknik observasi dokumentasi dengan melihat laporan keuangan perusahaan sampel. Data diperoleh melalui data dari situs resmi Bursa Efek Indonesia serta website yang terkait lainnya dengan cara mempelajari literatur yang berkaitan dengan permasalahan penelitian baik media cetak maupun elektronik. Teknik pengumpulan data selanjutnya melalui Studi keperpustakaan dengan cara membacara dan mengutip buku-buku, jurnal, artikel, media masa, dan jurnal terdahulu yang berhubungan dengan penelitian yang dilakukan.

Teknik analisa data yang digunakan adalah analisis deskriptif dilihat dari nilai mean, nilai maksimum, nilai minimum dan standar deviasi, selain itu teknik analisa data yang digunakan adalah uji asumsi klasik seperti uji normalitas, uji multikolinieritas, uji heterokedastisitas dan uji autokorelasi. Uji Model dengan melihat hasil uji koefisien determinasi R2. Persamaan untuk menguji hipotesis secara keseluruhan dalam penelitian ini adalah sebagai berikut :

$Y=\alpha+\beta_{1} X_{1}+\beta_{2} X_{2}+\beta_{3} X_{3}+\beta_{4} X_{4}+\beta_{5} X_{5}+\beta_{6} X_{6} \varepsilon$

$Y \quad=$ Penghindaran Pajak (CETR)

$\alpha \quad=$ Konstanta

$X_{1}=$ Kepemilikan Saham Asing

$X_{2}=$ Kualitas Informasi Internal

$X_{3} \quad=$ Publisitas CEO

$X_{4}=$ ROA

$X_{5} \quad=$ Leverage

$X_{6}=$ Ukuran perusahaan

Untuk menguji hipotesis yang digunakan dalam penelitian ini adalah signifikansi pada analisis regresi SPSS. Uji hipotesis yang dimaksudkan yaitu melihat pengaruh antar variabel independen terhadap variabel dependennya. Adapun criteria pengujian pada uji signifikansi penelitian ini, dengan melihat nilai signifikansi tersebut terhadap nilai 0,05. Jika nilai signifikansi $<0,05$ maka dapat disimpulkan variabel independen pengaruh signfikan terhadap variabel dependen. Sebaliknya, jika nilai signifikansi $>0,05$ maka variabel independen tidak 
mempunyai pengaruh secara signifikan terhadap variabel dependennya.

\section{HASIL DAN PEMBAHASAN}

Hasil analisis deskriptif dapat diperlihatkan pada tabel 1 berikut ini:

Tabel 1. Descriptif Statistik

\begin{tabular}{lrrrrr}
\hline & & & & \multicolumn{1}{c}{ Std. } \\
& N & Minimum & Maximum & \multicolumn{1}{c}{ Mean } & \multicolumn{1}{c}{ Deviation } \\
\hline CETR & 189 & .10 & .60 & .3017 & .12085 \\
KSA & 189 & .00 & 1.00 & .7116 & .21806 \\
KII & 189 & 94.00 & 181.00 & 117.0794 & 8.40966 \\
PCEO & 189 & 13.85 & 92.98 & 59.06 & 17.96463 \\
ROA & 189 & .10 & .59 & .2874 & .13125 \\
LEV & 189 & .10 & .98 & .4851 & .22206 \\
UKP & 189 & 6.64 & 13.93 & 11.3682 & 1.90996 \\
\hline Sumber: Data Olahan Sekunder, 2020 & & & &
\end{tabular}

Sumber: Data Olahan Sekunder, 2020

Hasil uji normalitas menunjukkan bahwa titik-titik mengikuti dan mendekati garis diagonalnya sehingga dapat disimpulkan bahwa model regresi memenuhi asumsi normalitas. Uji Collinearity Statistics (VIF) dilakukan dengan melihat nilai multikolinieritas yang baik dalam model regresi $<10$. Jika nilai variabel bebas tersebut $<10$ maka dapat dikatakan variabel tersebut layak digunakan dalam pengujian model regresi. Adapun hasil pengujian multikolinieritas dapat diperlihatkan pada tabel 2 dibawah ini:

Tabel 2. Uji Multikolinieritas

\begin{tabular}{cccc}
\hline & \multicolumn{2}{c}{ Collinearity Statistics } & \\
Model & Tolerance & VIF & Keterangan \\
\hline KSA & .926 & 1.080 & Bebas Multikolinearitas \\
KII & .977 & 1.024 & Bebas Multikolinearitas \\
PCEO & .976 & 1.025 & Bebas Multikolinearitas \\
ROA & .976 & 1.024 & Bebas Multikolinearitas \\
LEV & .958 & 1.044 & Bebas Multikolinearitas \\
UKP & .884 & 1.131 & Bebas Multikolinearitas \\
\hline
\end{tabular}

Sumber: Data Olahan Sekunder, 2020

Hasil uji heterokedastisitas dalam penelitian ini menunjukkan pada tampilan grafik scatterplots dari variabel dependen yaitu penghindaran pajak bahwa titik-titik menyebar di atas dan di bawah angka 0 pada sumbu Y, hal ini berarti bahwa model penelitian ini telah terbebas dari heteroskedastisitas. Hasil uji autokorelasi diperoleh angka DW sebesar 1,93 dalam tabel DW untuk $\mathrm{k}=7$ dan $\mathrm{N}=189$. Sedangkan nilai batas bawah (dl) sebesar 1,68 dan nilai batas atas (du) sebesar 1,83. Oleh karena nilai DW 1,93 lebih besar dari batas atas (du) 1,83 dan kurang dari (4-du) 2,16 atau 1,83<1,93<2,16, maka kesimpulan yang dapat diambil adalah tidak terdapat autokorelasi. Uji kelayakan Model (R Square) adalah uji yang bertujuan 
untuk melihat kelayakan model dalam regresi. Model yang baik adalah model yang dapat menjelaskan atau besar pengaruhnya variabel bebas terhadap variabel dependent-nya. Pengujian kelayakan model dapat dilihat salah satunya dari nilai R Square Adjusted. Semakin besar nilai ini maka semakin baik model yang dihasilkan dalam pengujian. Berdasarkan hasil uji koefisien deteminasi, nilai R2 (R Square) dari model regresi digunakan untuk mengetahui seberapa besar kemampuan variabel bebas (independent) dalam menerangkan variabel terikat (dependent). Dari tabel diatas diketahui bahwa nilai R2 sebesar 0,143, hal ini berarti bahwa 14,3\% yang menunjukkan bahwa penghindaran pajak dipengaruhi oleh variabel kepemilikan saham asing, kualitas informasi internal, publisitas CEO, return on assets, leverage, dan ukuran perusahaan. Sisanya sebesar 85,7\% dipengaruhi oleh variabel lain yang belum diteliti dalam penelitian ini. Hasil pengujian pada penelitian ini dapat dilihat pada tabel 3 berikut:

Tabel 3. Analisi Regresi dan Uji Hipotesis

\begin{tabular}{|c|c|c|c|c|c|c|}
\hline Variabel & $\begin{array}{c}\text { Unstandardized } \\
\text { Coefficients } \\
\text { B }\end{array}$ & $\begin{array}{c}\text { Standardized } \\
\text { Coefficients } \\
\text { Beta }\end{array}$ & Hipotesis & $\mathrm{T}$ & Sig & Keterangan \\
\hline (Constant) & .329 & & & 2.626 & .009 & \\
\hline KSA & -.082 & -.147 & Negatif & -2.067 & .040 & $\begin{array}{l}\text { Hipotesis } \\
\text { Diterima }\end{array}$ \\
\hline KII & -.002 & -.143 & Positif & -2.063 & .040 & $\begin{array}{l}\text { Hipotesis } \\
\text { Ditolak }\end{array}$ \\
\hline PCEO & .001 & .152 & Positif & 2.182 & .030 & $\begin{array}{l}\text { Hipotesis } \\
\text { Diterima }\end{array}$ \\
\hline ROA & .118 & .128 & Positif & 1.847 & .066 & $\begin{array}{l}\text { Hipotesis } \\
\text { Ditolak }\end{array}$ \\
\hline LEV & .107 & .197 & Positif & 2.805 & .006 & $\begin{array}{l}\text { Hipotesis } \\
\text { Diterima }\end{array}$ \\
\hline UKP & .011 & .175 & Positif & 2.403 & .017 & $\begin{array}{c}\text { Hipotesis } \\
\text { Diterima }\end{array}$ \\
\hline
\end{tabular}

Sumber : Data Olahan Sekunder, 2020

Berdasarkan tabel diatas dapat dianalisis model estimasi sebagai berikut: Penghindaran Pajak = 0,329- 0,082 KSA - 0,002 KII + 0,001 PCEO + 0,118 ROA + 0,107

$$
\mathrm{LEV}+0,011 \mathrm{UKP}+\mathrm{e}
$$

Dari tabel 3 di atas juga dapat dijelaskan bahwa hasil interpretasi atas hipotesis penelitian yang diajukan dapat dilihat sebagai berikut:

\section{Kepemilikan saham asing berpengaruh negatif terhadap penghindaran pajak (H1)}

Hasil Uji t untuk H1 diperoleh hasil t hitung sebesar 2.067 dengan signifikansi $\rho$ sebesar 0,040. Nilai signifikan untuk variabel kepemilikan saham asing menunjukkan nilai dibawah 
tingkat signifikan sebesar 5\% $(\alpha=0,05)$ atau $\rho<0,05$ dan nilai thitung 2,067 $>$ ttabel 1,973 yang artinya bahwa $\mathrm{H} 1$ diterima. sehingga kepemilikan saham asing berpengaruh negatif signifikan terhadap penghindaran pajak. Kepemilikan saham asing pada suatu perusahaan akan mempengaruhi kebijakan perusahaan mengenai penghindaran pajak. Hal ini menunjukan bahwa semakin besar porsi kepemilikan asing, maka nilai CETR semakin kecil. Penghindaran pajak dinilai dengan besarnya pembayaran pajak, jadi semakin kecil nilai CETR mengindikasikan adanya kenaikan atau peningkatan penghindaran pajak. Sehingga semakin besar porsi kepemilikan asing perusahaan semakin akan menghindari pajak. Pemegang saham asing yang mendominasi suatu perusahaan akan mempengaruhi manajemen dalam menentukan kebijakan yang akan menguntungkan mereka, seperti kebijakan mengenai perpajakan perusahaan untuk membayar pajak sesuai dengan ketentuan yang berlaku. Hasil penelitian ini sejalan dengan hasil penelitian Salihu, Annuar, dan Obid (2015) yang menyatakan bahwa kepemilikan saham asing berpengaruh terhadap penghindaran pajak. Menurut teori agency akan muncul sebuah agency problem yaitu perbedaan keinginan antara principle dan agen, ketika satu pihak (principal) mempekerjakan pihak lain (agen) untuk melaksanakan suatu pekerjaan dengan memberikan pihak lain tersebut wewenang Semakin besar saham yang dimiliki pihak asing pada suatu perusahaan, maka semakin besar juga suara investor untuk ikut adil dalam penentuan kebijakan perusahaan.

\section{Kualitas informasi internal berpengaruh negatif terhadap penghindaran pajak (H2)}

Hasil Uji t untuk H2 diperoleh hasil t hitung sebesar 2.063 dengan signifikansi sebesar 0,040. Nilai signifikan untuk variabel kualitas informasi internal menunjukkan nilai dibawah tingkat signifikan sebesar 5\% $(\alpha=0,05)$ atau $\rho<0,05$ dan nilai thitung $>$ t tabel yang artinya $\mathrm{H} 2$ yang menyatakan kualitas informasi internal berpengaruh positif terhadap penghindaran pajak ditolak. Kualitas informasi internal yang diukur dengan kecepatan perusahaan mengumumkan laporan tahunan pada BEI yang mencerminkan kemampuan perusahaan dalam mengintegrasikan informasi internal yang mudah dan cepa tmempengaruhi penghindaran pajak perusahaan. Hal ini berarti perusahaan memiliki informasi yang berkualitas sehingga mampu merumuskan kebijakan yang telah ditetapkan yang pada akhirnya mampu menyampaikan laporan tahunannya tepat waktu. Manajemen perusahaan akan menghasilkan kebijakan perusahaan salah satunya penghindaran pajak perusahaan yang efektif jika manajemen memiliki informasi dari internal perusahaan. Informasi yang berasal dari para pekerja yang terjun langsung dalam proses usaha perusahaan, akan memberikan masukan kepada manajemen sebelum menentukan tindakan penghindaran pajak seperti apa yang akan digunakan perusahaan. Namun pengelolaan informasi internal tidaklah gampang, 
kualitas informasi internal yang baik memerlukan kordinasi yang baik pula dalam lini-lini yang ada di perusahaan (Mutmainah, 2014). Hasil penelitian ini didukung dengan hasil penelitian (Ghafoori \& Rahmani, 2017), yang mendapati hasil kualitas informasi internal berpengaruh pada penghindaran pajak perusahaan yang terdaftar di Bursa Efek Teheran. Kualitas informasi internal pada penghindaran pajak lebih tinggi pada perusahaan-perusahaan di mana informasi memainkan peran yang lebih penting seperti perusahaan yang tersebar diberbagai wilayah dan perusahaan dengan berbagai sektor.

\section{Publisitas CEO berpengaruh positif terhadap penghindaran pajak (H3)}

Hasil Uji t untuk H3 diperoleh hasil t hitung sebesar 2,182 dengan signifikansi sebesar 0,030. Nilai signifikan untuk variabel publisitas CEO menunjukkan nilai dibawah tingkat signifikan sebesar 5\% $(\alpha=0,05)$ atau $\rho<0,05$ dan nilai thitung $>$ t tabel yang artinya H3 yang menyatakan publisitas CEO berpengaruh positif terhadap penghindaran pajak diterima. Semakin tinggi publisitas CEO suatu perusahaan maka akan mempengaruhi tindakan penghindaran pajak perusahaan. Publisitas CEO merupakan tingkat kepopuleran seorang yang diperolehnya dari kepiawaiannya memimpin perusahaan, sehingga perusahaan tersebut dikenal publik. CEO dengan publisitas yang tinggi, akan menjaga nama baiknya dan mampu mengatasi berbagai permasalahan pada perusahaan. Ketika kondisi perekonomian yang tidak mendukung perusahaan untuk menghasilkan laba, CEO dengan publisitas tinggi akan mengupayakan pemabayaran pajak yang kecil dengan cara melalui penghindaran pajak secara legal sehingga pemegang saham menerima pembagian laba atau dividen. Hasil penelitian ini didukung oleh (Duan et al., 2018), yang menunjukkan bahwa CEO dengan publisitas tinggi lebih cenderung menggunakan penghindaran pajak untuk meningkatkan laba yang dilaporkan dan memenuhi harapan kinerja pasar.

\section{Return On Assets (ROA) tidak berpengaruh terhadap penghindaran pajak (H4)}

Hasil Uji t untuk H3 diperoleh hasil thitung sebesar 1,847 dengan signifikansi sebesar 0,066. Nilai signifikan untuk variabel ROA menunjukkan nilai diatas tingkat signifikan sebesar 5\% $(\alpha=0,05)$ atau $\rho>0,05$ dan nilai $\mathrm{t}$ hitung $<\mathrm{t}$ tabel yang artinya $\mathrm{H} 4$ yang menyatakan ROA berpengaruh positif terhadap penghindaran pajak ditolak. Return On Assets tidak mempengaruhi penghindaran pajak perusahaan. Penghindaran pajak merupakan aktivitas yang beresiko, sehingga manajemen perusahaan akan meminimalisir kemungkinan yang akan terjadi dikemudian hari. Penghindaran pajak dapat juga membebankan biaya yang signifikan terhadap perusahaan dan manajer mereka, termasuk biaya yang dibayarkan kepada konsultan pajak, waktu yang dihabiskan untuk penyelesaian audit pajak, denda reputasi, dan denda yang dibayarkan kepada otoritas pajak (Rachmithasari, 2015). Hasil penelitian ini 
sejalan dengan penelitian yang dilakukan oleh Rachmithasari (2015) dan Marfu'ah (2015) yang menyatakan bahwa ROA tidak berpengaruh terhadap tax avoidance.

\section{Leverage (LEV) berpengaruh positif terhadap penghindaran pajak (H5)}

Hasil Uji t untuk H5 diperoleh hasil t hitung sebesar 2,805 dengan signifikansi sebesar 0,006. Nilai signifikan untuk variabel Leverage menunjukkan nilai dibawah tingkat signifikan sebesar $5 \%(\alpha=0,05)$ atau $\rho<0,05$ dan nilai thitung $>$ t tabel yang artinya H5 yang menyatakan Leverage berpengaruh positif terhadap penghindaran pajak diterima. Perusahaan yang memiliki Leverage akan melakukan penghindaran pajak. Oleh karena itu perusahaan yang memiliki nilai rasio leverage yang tinggi menunjukkan semakin tinggi jumlah pendanaan dari utang pihak ketiga yang digunakan perusahaan dan semakin tinggi pula biaya bunga yang timbul dari utang tersebut. Biaya bunga yang semakin tinggi akan memberikan pengaruh berkurangnya laba yang dapat mengurangi beban pajak perusahaan, sehingga minimnya pembayaran pajak pada perusahaan tersebut. Hal ini sejalan dengan penelitian yang dilakukan Rachmithasari (2015), Heryuliani (2015). Marfu'ah (2015) memberikan bukti bahwa perusahaan yang memiliki kewajiban pajak tinggi akan memilih untuk berutang agar mengurangi pajak. Dengan sengajanya perusahaan berutang untuk mengurangi beban pajak maka dapat disebutkan bahwa perusahaan tersebut melakukan penghindaran pajak. Jadi semakin tinggi leverage suatu perusahaan maka pemabayaran pajak menjadi minim dan ini menyebabkan indikasi tingkat penghindaran pajak yang tinggi.

\section{Ukuran Perusahaan (UKP) berpengaruh positif terhadap penghindaran pajak (H6)}

Hasil Uji t untuk H6 diperoleh hasil t hitung sebesar 2,403 dengan signifikansi sebesar 0,017. Nilai signifikan untuk variabel ukuran perusahaan menunjukkan nilai dibawah tingkat signifikan sebesar 5\% $(\alpha=0,05)$ atau $\rho<0,05$ dan nilai thitung $>\mathrm{t}$ tabel yang artinya H6 yang menyatakan ukuran perusahaan berpengaruh positif terhadap penghindaran pajak diterima. Semakin besar ukuran suatu perusahaan maka akan mempengaruhi tindakan penghindaran pajak perusahaan. Perusahaan besar lebih memiliki aktivitas operasi perusahaan yang lebih banyak dan rumit sehingga terdapat celah-celah untuk dimanfaatkan dalam keputusan tax avoidance. Selain itu perusahaan yang beroperasi lintas negara memiliki kecenderungan untuk melakukan tindakan tax avoidance yang lebih tinggi dibandingkan perusahaan yang beroperasi lintas domestik, karena mereka bisa melakukan transfer laba ke perusahaan yang ada di negara lain, dimana negara tersebut memungut tarif pajak yang lebih rendah dibandingkan negara lainnya (Marfu'ah, 2015). Hal ini sejalan dengan penelitian yang dilakukan oleh Sari (2014) dan Rinaldi dan Charoline Cheisviyanny (2015). 


\section{KESIMPULAN DAN SARAN}

Berdasarkan hasil penelitian dan pembahasan yang telah disajikan pada bab-bab sebelumnya, maka dapat diambil kesimpulan sebagai berikut; (1) Kepemilikan saham asing berpengaruh negatif terhadap penghindaran pajak, hal ini menunjukan bahwa semakin besar porsi kepemilikan asing, maka nilai CETR semakin kecil. (2) Kualitas informasi internal berpengaruh negatif terhadap penghindaran pajak, hal ini menunjukkan bahwa semakin tinggi kualitas informasi internal perusahaan maka ada indikasi tindakan penghindaran pajak perusahaan secara signifikan. (3) Publisitas CEO berpengaruh positif terhadap penghindaran pajak, hal ini menunjukkan bahwa CEO dengan publisitas tinggi akan mengupayakan pemabayaran pajak yang kecil sehingga nilai CETR kecil dan adanya indikasi penghindaran pajak. (4) Return on Asset tidak berpengaruh terhadap penghindaran pajak, hal ini menunjukkan bahwa ROA merupakan indikator kemampuan perusahaan dalam menghasilkan laba sehingga ROA merupakan faktor penting dalam pengenaan pajak penghasilan bagi perusahaan. (5) Leverage berpengaruh positif terhadap penghindaran pajak, hal ini menunjukkan perusahaan yang memiliki nilai rasio leverage yang tinggi menunjukkan semakin tinggi jumlah pendanaan dari utang pihak ketiga yang digunakan perusahaan dan semakin tinggi pula biaya bunga yang timbul dari utang tersebut. Biaya bunga yang semakin tinggi akan memberikan pengaruh berkurangnya laba yang dapat mengurangi beban pajak perusahaan, sehingga minimnya pembayaran pajak pada perusahaan. (6) Ukuran perusahaan berpengaruh positif terhadap penghindaran pajak, Hal ini menunjukkan bahwa perusahaan besar memengaruhi secara signifikan menurunnya praktik penghindaran pajak yang dapat terjadi.

Berdasarkan evaluasi atas hasil penelitian ini, beberapa saran yang diharapkan dapat menjadi bahan pertimbangan untuk berbagai pihak, antara lain; (1) Bagi perusahaan, Perusahaan pertambangan agar lebih berhati-hati dalam mengambil keputusan yang terkait dengan perencanaan pajak terutama mengenai tax avoidance yang dilakukan agar terhindar dari sanksi administrasi pajak dan kesalahpahaman investor sehingga membentuk persepsi yang buruk kepada perusahaan. (2) Bagi investor, Sebaiknya dalam pengambilan keputusan investasi untuk mengkaji terlebih dahaulu bagaimana kinerja suatu perusahaan dan tetap mematuhi peraturan tentang perpajakan, penghindaran pajak bukan hal illegal namun perlu kehati-hatian dalam mengambil kebijakan agar tidak melewati batas undang-undang. Apa bila terjadi kekeliruan terhadap persepsi undang-undang, maka tax avoidance akan memberikan dampak yang kurang baik untuk semua belah pihak yang bersangkutan baik dari pihak investor, perusahaan maupun pemerintah. (3) Bagi penelitian selanjutnya; (a) 
Menambah variabel penelitian karena masih banyak faktor-faktor yang berkontribusi dalam mempengaruhi tax avoidance seperti variabel reformasi perpajakan, kualitas audit, risiko perusahaan, karakter eksekutif, kompensasi rugi fiskal dan koneksi politik. (b) Sampel perusahaan hanya perusahaan pertambangan, penelitian selanjutnya diharapkan dapat meneliti tax avoidance dengan menambah sampel perusahaan pada sektor yang berbeda.

\section{REFERENSI}

Ajie, R. (2015). Pengaruh Karakter Eksekutif, Kepemilikan Keluarga, Profitabilitas dan Corporate Governance terhadap Penghindaran Pajak di Indonesia (Studi pada Perusahaan Manufaktur yang Terdaftar di BEI Tahun 2010 - 2014). Universitas Muhammadiyah Yogyakarta.

Ardansyah, D. (2014). Pengaruh Size, Leverage, Profitaliby, Capital Intensity Ratio dan Komisaris Independen terhadap Effective Tax Rate (ETR). Skripsi. Universitas Diponegoro.

Ardiana, I. M. S. dharma \& P. A. (2015). Pengaruh Leverage, Intensitas Aset Tetap, Ukuran perusahaan dam Koneksi Politik Terhadap Tax Avoidance. Jurnal Akuntansi Universitas Udayana.

Darmawan, I., \& Sukartha, I. (2014). Pengaruh Penerapan Corporate Governance, Leverage, Roa, dan Ukuran Perusahaan Pada Penghindaran Pajak. E-Jurnal Akuntansi, 9(1), 143 161.

Duan, T., Ding, R., Hou, W., \& Zhang, J. Z. (2018). The burden of attention: CEO publicity and tax avoidance. Journal of Business Research, 87(February), 90-101. https://doi.org/10.1016/j.jbusres.2018.02.010

Fahmi, I. (2012). Analisis Laporan Keuangan. Bandung: Alfabeta.

Gallemore, J., \& Labro, E. (2015). The importance of the internal information environment for tax avoidance. Journal of Accounting and Economics, 60(1), 149-167. https://doi.org/10.1016/j.jacceco.2014.09.005

Ghafoori, J., \& Rahmani, M. (2017). Impacts of Firms' Internal Information Environment on Tax Avoidance (Case Study: Companies Listed in Tehran's Stock Exchange). Journal of History Culture and Art Research, 6(1), 106. https://doi.org/10.7596/taksad.v6i1.708

Hardika, S. N. (2007). Perencanaan Pajak sebagai Strategi Penghematan Pajak. Jurnal Bisnis Dan Kewirausahaan, Volume $3 \mathrm{~N}$.

Heryuliani, N. (2015). Pengaruh Karakteristik Perusahaan dan Kepemilikan Keluarga Terhadap Penghindaran Pajak. Skripsi. Universitas Islam Negeri Syarif Hidayatullah. Jakarta.

Luh, N., \& Puspita, P. (2017). Pengaruh Ukuran Perusahaan, Leverage, Profitabilitas dan Corporate Social Responsibility terhadap Penghindaran Pajak (Tax Avoidance). EJurnal Akuntansi, 21(2), 882-911. https://doi.org/10.24843/EJA.2017.v21.i02.p01

MARFU'AH, L. (2015). Pengaruh Return on Asset, Leverage, Ukuran Perusahaan Kompensasi Rugi Fiskal dan Koneksi Politik terhadap Tax Avoidance. JOM Fekon, 4(1), 1671-1684.

Ngadiman, N., \& Puspitasari, C. (2014). Pengaruh Leverage, Kepemilikan Institusional, dan Ukuran Perusahaan terhadap Penghindaran Pajak (Tax Avoidance) pada Perusahaan Sektor Manufaktur yang Terdaftar di Bursa Efek Indonesia 2010-2012. Jurnal Akuntansi, 18(3), 408-421. https://doi.org/10.24912/ja.v18i3.273

Prakosa, K. B. (2014). Pengaruh Profitabilitas, Kepemilikan Keluarga dan Corporate Governance terhadap Penghindaran Pajak Di Indonesia. Simposium Nasional Akuntansi 
XVII.

Puspitawati, L. dan S. D. A. (2011). Sistem Informasi Akuntansi. Yogyakarta: Graha Ilmu.

Putri, N., \& Fadhlia, W. (2017). Pergantian CEO, Penghindaran Pajak, Kompensasi Eksekutif dan Manajemen Laba Studi Kausalitas Pada Perusahaan Manufaktur Indonesia. 2(3).

Rachmitasari, annisa fadhila. (2015). Pengaruh Return On Assets, Leverage, Corporate Governance, Ukuran Perusahaan dan Kompensasi Rugi Fiskal pada Tax Avoidance (Perusahaan Manufaktur yang Terdaftar di Bursa Efek Indonesia Tahun 2011-2013). Accounting, 1-19.

Rusydi, M. K. R. dan D. M. (2014). Pengaruh Struktur Kepemilikan Terhadap Aggresive Tax Avoidance. Simposium Nasional Akuntansi XVII. Pp. 1-19.

Salihu, I. A., Annuar, H. A., \& Sheikh Obid, S. N. (2015). Foreign investors' interests and corporate tax avoidance: Evidence from an emerging economy. Journal of Contemporary Accounting and Economics, 11(2), 138-147. https://doi.org/10.1016/j.jcae.2015.03.001

Sari, T. K. dan M. M. R. (2013). Pengaruh Return On Assets, Leverage, Corporate Governance, Ukuran Perusahaan, dan Kompensasi Rugi Fiskal pada Tax Avoidance. Buletin Studi Ekonomi Vol 18, No.1, 58-65.

Sinambela, T. (2019). Pengaruh Return On Assets, Leverage Dan Ukuran Perusahaan Terhadap Penghindaran Pajak (Tax Avoidance). 1(April), 68-86. 